\title{
Assessing maturity, fecundity and hermaphroditism in blue cod Parapercis colias
}

\author{
K. K. Brandt ${ }^{1,3, *}$, M. R. Dunn ${ }^{1}$, S. L. Brouwer ${ }^{2}$ \\ ${ }^{1}$ School of Biological Sciences, Victoria University of Wellington, PO Box 600, Wellington 6140, New Zealand \\ ${ }^{2}$ Oceanic Fisheries Programme, Pacific Community (SPC), BP D5, Noumea 98848, New Caledonia \\ ${ }^{3}$ Present address: 100-104 Stoke Newington High Street, London N16 7NY, UK
}

\begin{abstract}
Macroscopic assessments of maturity from whole fish gonads are well established and routinely used in fisheries research and are important in the estimation of size-at-maturity and the impacts of size-selective fishing. Histological assessment of maturity is more accurate, but much slower, more expensive, and so less frequently conducted. We made a comparison between macroscopic and histological maturity classifications for a diandric protogynous hermaphrodite, blue cod Parapercis colias. The agreement between macroscopic and histological maturity classifications was low. Female and male $L_{50}$ (length at which $50 \%$ of the fish are mature) was estimated from histological data as 23 and $26 \mathrm{~cm}$, respectively. Female spawning frequency was $4.6 \mathrm{~d}$, and mean $\pm \mathrm{SD}$ relative batch fecundity was $6.5 \pm 3.3$ hydrated oocytes per gram body weight. A single gonad with both testicular and ovarian tissue was found. Many blue cod were assigned incorrect maturity classifications. These results warrant a study of early gonadal development in blue cod to elucidate if and how sex change takes place. Difficulties in determination of sex and maturity may be most pronounced for species, like blue cod, that have complex maturation patterns. For blue cod, a review of the macroscopic maturity classification key and more thorough technician training are called for.
\end{abstract}

KEY WORDS: Maturity assessment - Length at maturity - Fecundity - Parapercis colias · Sex change $\cdot$ Histology

\section{INTRODUCTION}

Sustainable management and assessment of fish stocks is dependent upon accurate knowledge of biological information, such as size- and age-atmaturity, fecundity and reproductive mode (Morgan 2008, Klibansky \& Scharf 2015). Size-at-maturity estimates are usually obtained from either macroscopic or histological evaluation of gonads and can be used in stock assessment models to help estimate the spawning-stock biomass (SSB; Klibansky \& Scharf 2015). Estimates of fecundity at size and age are important for accurately assessing population growth potential and evaluating the reproductive input of females at different sizes or ages

*Corresponding author: kasper.k.brandt@gmail.com
(Birkeland \& Dayton 2005, Beer et al. 2013). Female fecundity is correlated with fish size in most species and body condition in some species, and larger females can produce larger and higherquality eggs with greater larval success (Kamler 2005). Therefore, as the size structure, age structure and sex ratio change in a population, so may the overall fecundity, even when SSB remains constant. Population response to fishing pressure can depend upon the reproductive mode of the species, and in sex-changing species, fishing pressure can cause changes not just to the size at maturity, but to population sex ratios by influencing the frequency of sex change (Hawkins \& Roberts 2004, Alonzo et al. 2008).

() The authors 2017. Open Access under Creative Commons by Attribution Licence. Use, distribution and reproduction are unrestricted. Authors and original publication must be credited. 
Macroscopic maturity estimation is quick, cheap and does not require many resources; however, it can lack accuracy (Vitale et al. 2006). Histological maturity estimation is more accurate, but it is a costly, timeconsuming and resource-demanding process. Inaccuracy in macroscopic maturity assessment is a common feature of fisheries research. Klibansky \& Scharf (2015) presented a review of research comparing macroscopic and microscopic methods in estimating maturity in fishes. Of 18 species studied, only 2 had maturity stages that were estimated with $>90 \%$ agreement between macroscopic and microscopic techniques; agreement between techniques was as low as $31 \%$. Inaccuracy in maturity assessments will likely give rise to incorrect estimates of size and age at maturity, which can lead to inaccurate estimation of SSB. For example, Vitale et al. (2006) found that when macroscopic maturity data were used to estimate age at maturity, SSB was overestimated by up to $35 \%$ when compared with histological maturity estimates.

Blue cod Parapercis colias (Forster 1801) is a penguipedid (sandperches and weevers) endemic to New Zealand (Nelson 2006). It is most abundant off the South Island and Stewart Island, where it supports major commercial and recreational fisheries (Beentjes \& Carbines 2005, Cole et al. 2012). Blue cod are thought to be diandric protogynous hermaphrodites, where individuals initially mature as either male or female and some females change sex to male later in life (Carbines 2004). Blue cod abundance has decreased over the past few decades, particularly within the Marlborough Sounds, but the implications for maturity and sex composition of the stocks remains unknown (MPI 2015).

Sex change in blue cod has not been well described. Males are known to grow larger than females (MPI 2015). Mutch (1983) reported a single transitional gonad from a $37 \mathrm{~cm}$ total length (TL) blue cod caught at Leigh, New Zealand, and described the gonad as having resting-stage oocytes and all stages of spermatogenesis. Carbines (2004) found transitional gonads in 28 individuals (28.0-45.5 cm TL; 6-11 yr old) from a sample of 306 blue cod from Stewart Island. As with Mutch (1983), Carbines (2004) described the transitional gonads as having functional testes containing previtellogenic and/or vitellogenic oocytes. Diandry in blue cod was inferred from the presence of small sexually immature males in blue cod populations which were thought to be unlikely to have previously matured as females (Carbines 2004).

The macroscopic maturity staging key used for blue cod maturity has not been validated and therefore the accuracy of size and age at maturity esti- mates is unknown. Other histological maturity keys have been used by Mutch (1983) and Carbines (2004) to stage blue cod; however, these keys were inadequate as the classifications were based on relative proportions of tissues within the gonad, and the descriptions used subjective language.

The aims of this research were to (1) develop a simpler objective histological key; (2) evaluate the accuracy of the macroscopic maturity key; (3) use histological and gravimetric methods to estimate batch fecundity and spawning frequency; and (4) look for further evidence of hermaphroditism in blue cod.

\section{MATERIALS AND METHODS}

Blue cod samples were collected by the National Institute of Water and Atmospheric Research (NIWA) from Queen Charlotte Sound, Pelorus Sound, D'Urville Island and the Cook Strait, off the northeast coast of the South Island of New Zealand. The survey was carried out from 26 September to 9 November 2013 during the spawning season (Rapson 1956). Blue cod were caught with baited cod pots set for approximately $60 \mathrm{~min}$. Fish were weighed, measured from the tip of the snout to the end of the caudal fin (TL) and sexed, and maturity was assessed by macroscopic inspection of the fresh gonads at sea. Randomly selected gonads from 550 fish were removed, fixed in $10 \%$ neutrally buffered formalin and stored in $70 \%$ ethanol. Technicians working for NIWA collected the samples and macroscopically staged the fish. The authors carried out the histological assessments.

The gonads were macroscopically staged, fresh on the vessel, using a 6-stage classification, similar to a 5 -stage method used in previous blue cod surveys (Beentjes \& Carbines 2012), except that immature and spent stages were separated in the 6-stage key. Gonads were staged as follows: (1) immature; (2) maturing (oocytes visible in females); (3) mature (hyaline oocytes in females, milt expressible in males); (4) running ripe (eggs or milt free-flowing); (5) spent; (6) resting.

A subsample of 252 gonads from the preserved gonads was taken; all females and fish of unknown sex were included, and at least 5 males were chosen at random from each $1 \mathrm{~cm}$ length bin. In length bins with fewer than 5 males, all male fish were included in the subsample. Unfortunately, some of the gonads in the subsample were not preserved well enough for histological processing. Gonads were removed from the alcohol, photographed, blotted dry and weighed 
to the nearest $0.001 \mathrm{~g}$. Transverse sections of ca. $4 \mathrm{~mm}$ thickness were taken for histological processing (see below). Tissue dehydration and wax impregnation was done using an automated tissue processor. Samples were then embedded in paraffin wax, and $5 \mu \mathrm{m}$ sections were cut using a microtome and mounted on glass slides. Slides were left overnight to dry and then stained with haematoxylin and eosin (H \& E). Finally, coverslips were attached with DPX mounting medium.

Developmental differences between left and right lobes of the gonad, and along the length of the lobes, were investigated by sectioning a random subsample of 27 gonads at the anterior, middle and posterior regions of both lobes. Apart from a single gonad where the lobes were intertwined and were of testicular and ovarian tissue, histological sex identification and evaluation of histological maturity stage for this subsample revealed no difference in histologically determined maturity between lobes or along the length of the lobes. Thereafter, all samples were taken from the middle region of the right lobe, or a medial section containing both left and right lobes was taken where individual lobe dissection was not possible.

Histological slides were examined at $80-400 \times$ magnification using transmitted light. A new sexspecific histological maturity key was developed for blue cod during this study. The key was developed by examining a variety of gonads at various stages of development and comparing them to the histological maturity stages used for carpenter seabream Argyrozona argyrozona (Brouwer \& Griffiths 2005) and butterfish Odax pullus (Trip et al. 2011). Females were classified by the most advanced oogenic stage found within the gonad section (West 1990) and the presence of atretic oocytes. Females in the spawning class were classified as containing oocytes in the spawning or post-spawning phase (Brown-Peterson et al. 2011). Oocyte development stage and atretic oocytes were identified using the criteria of McMillan (2007). Males were graded by the most advanced and most abundant stage of spermatogenesis (Grier 1981), the appearance of connective tissue and abundance of spermatozoa in the primary sperm duct.

The 5 female maturity stages were characterised as: (1) most advanced stage is the cortical alveolus stage, pre-vitellogenic oocytes predominate (immature or resting); (2) early vitellogenic oocytes are the most advanced stage, no germinal vesicle migration or hydrating oocytes present (developing); (3) early stages of hydration and germinal vesicle migration are the most advanced stages (mature); (4) hydrated oocytes are the most advanced stage (ripe/ running); and (5) late stage vitellogenic oocytes and early hydrating oocytes (yolked oocytes) are atretic (spent).

The male maturity stages were classified as: (1) connective tissue abundant, sperm sinuses undeveloped, spermatogonia dominate (immature or resting); (2) sperm sinuses begin to develop, spermatocytes dominate, and spermatids are present (developing); (3) sperm sinuses fill with spermatozoa, spermatozoa predominant throughout the testis, primary sperm duct begins to fill with spermatozoa (mature); (4) primary sperm duct is packed with spermatozoa, major sperm ducts appear within the lobes of the testis and are filled with spermatozoa (ripe/running); (5) sperm sinuses begin to empty, outer margins of testis dominated by loose connective tissue, residual spermatozoa remains within the primary sperm duct (spent).

All ovarian histological sections were examined for the presence of postovulatory follicles (POFs) and atretic oocytes. POFs were graded as stage 1, 2 or 3 (Fig. 1) by comparing them to known-age POFs of carpenter seabream (Brouwer \& Griffiths 2005). Stage 1 POFs were determined from a loosely arranged string of follicle cells with conspicuous lumen. Stage 2 POFs were more densely packed, and the lumen was still clearly visible. Stage 3 POFs were small, tightly packed clusters of follicle cells.

Size-at-maturity was modelled for females and males separately using 2-parameter logistic ogives fitted to the proportion of mature fish at length in $1 \mathrm{~cm}$ length bins. In the histological and macroscopic analyses, stages 3 and above were classified as mature. Macroscopic stages 1 and 6 were combined to be consistent with previous surveys, and to be comparable with the histological stages. Maturity ogives were fitted to macroscopic and histological data using the subsample $(\mathrm{n}=252$ ) (Table 1$)$, and macroscopic maturity ogives were also fitted using the larger survey sample $(\mathrm{n}=3247)$.

The 2-parameter logistic ogives had the form:

$$
p_{i}=\frac{1}{1+19^{-\left(L_{i}-L_{50}\right) / L_{\mathrm{to} 95}}}
$$

where $p_{i}$ is the proportion of mature fish in size class $i_{i} L_{i}$ is the length of size class $i_{i} L_{50}$ is the length at which $50 \%$ of the fish are mature (stage $3+$ ); and $L_{\text {to95 }}$ is the difference between the length at which $95 \%$ of the fish are mature and the $L_{50}$. Model parameters $L_{50}$ and $L_{\text {to95 }}$ were estimated by minimising sums of the squared residuals, using the nls function in R ( $\mathrm{R}$ Core Team 2015). Macroscopic and histological logistic maturity ogives were modelled in the same manner. 


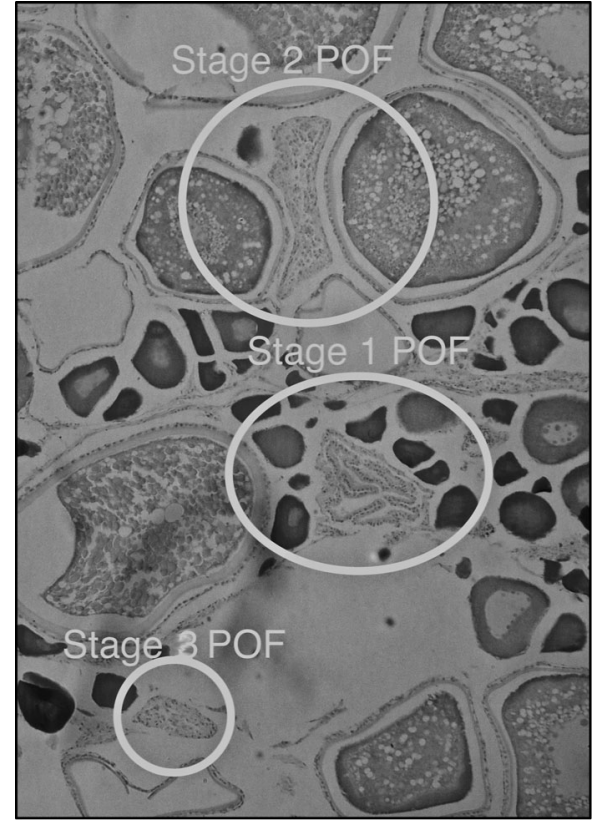

Fig. 1. Stage 1, 2 and 3 postovulatory follicles (POFs) from a histological section of a blue cod Parapercis colias ovary stained with haematoxylin and eosin. Stage 1 POFs were defined as being more densely packed and the lumen was still clearly visible. Stage 3 POFs were small, tightly packed clusters of follicle cells

Table 1. Subsample of blue cod Parapercis colias gonads by macroscopically determined sex and length class processed for histological analysis

\begin{tabular}{|lrcc|}
\hline Total length $(\mathrm{cm})$ & Female & Male & Unknown sex \\
\hline $15-19$ & 5 & 0 & 0 \\
$20-24$ & 14 & 9 & 3 \\
$25-29$ & 49 & 25 & 5 \\
$30-34$ & 51 & 44 & 1 \\
$35-39$ & 5 & 28 & 0 \\
$40-44$ & 0 & 13 & 0 \\
Total & 124 & 119 & 9 \\
\hline
\end{tabular}

All ovaries that contained hydrated oocytes and did not contain POFs were selected for fecundity analysis. Ten females met these criteria. In addition, fecundity estimates for a random subsample of 11 ovaries that contained both hydrated oocytes (HOs) and early-stage POFs was undertaken.

Fecundity was estimated using the gravimetric method. A ca. $1 \mathrm{~g}$ section from the right ovary was removed, blotted dry and weighed to the nearest $0.001 \mathrm{~g}$. The section was then teased apart under running water over a $250 \mu \mathrm{m}$ mesh sieve to separate all developing oocytes. The oocytes were transferred to a Bogorov tray, and the HOs were counted under a dissecting microscope using dark-field light. HOs were identified by their comparatively large size, translucent ooplasm and presence of a large yolk sac. Batch fecundity was calculated as:

$$
F=F_{s} \times\left(W_{o} / W_{s}\right)
$$

where $F$ is batch fecundity; $F_{S}$ is the number of hydrated oocytes in the ovary section; $W_{o}$ is the blotted weight of the ovaries; and $W_{s}$ is the blotted ovary section weight.

Spawning fraction was calculated by dividing the number of females with early-stage POFs by the total number of mature females. The spawning fraction is the daily proportion of mature females that had spawned that day, indicated by early-stage POFs. The spawning fraction was inverted to give an estimate of spawning frequency (Hunter \& Macewicz 1985). Annual fecundity was calculated as:

$$
A_{f}=\left(\frac{l_{s}}{S_{f}}\right) \times f_{b}
$$

where $A_{f}$ is the annual fecundity; $l_{s}$ is the length of the spawning season (days); $S_{f}$ is the spawning frequency; and $f_{b}$ is the batch fecundity.

Evidence for hermaphroditism was investigated using the histological sections of gonads. Evidence for protogynous hermaphroditism in testicular structure was identified as remnant oocytes and follicles or a testis structure resembling ovarian lamellae or still containing the ovarian lumen (Wilson \& Nieland 1994). Sex-changing individuals were recognised by the presence of both ovarian and testicular tissue within the same gonad. A large central cavity in testes was also considered to be evidence of potential sex change, following Sadovy \& Shapiro (1987) and Siau (1994), who found in bluehead wrasse Thalassoma bifasciatum (another diandric protogynous hermaphrodite) that a large central cavity in the gonads of secondary males was not present in primary males.

\section{RESULTS}

\section{Maturity classification}

Despite methodological differences between the assessment techniques, comparison of discrete histological and macroscopic maturity stages was informative, as the analysis quantified the agreement of broadly defined macroscopic stages to precisely defined histological stages, illustrating the accuracy of the macroscopic maturity assessments. Comparing macroscopic staging to the microscopic staging re- 
Table 2. Macroscopic maturity classifications compared with histological maturity classification in blue cod Parapercis colias. In this table, individuals that were macroscopically staged as immature or resting are pooled in immature. M: male, F: female, Stages 1: immature/resting, 2: developing, 3: mature, 4: ripe/running, 5: spent

\begin{tabular}{|cccccccccccc|}
\hline Macroscopic & & F 1 & F 2 & F 3 & F 4 & F 5 & M 1 & M 2 & M 3 & M 4 & M 5 \\
\hline Histological & F 1 & 0 & 1 & 1 & 0 & 14 & & & & & \\
& F 2 & 0 & 2 & 1 & 0 & 1 & & & & & \\
F 3 & 0 & 1 & 6 & 1 & 37 & & & & & \\
F 4 & 0 & 0 & 10 & 4 & 19 & & & & & \\
F 5 & 0 & 1 & 12 & 0 & 13 & & & & & \\
M 1 & & & & & & 4 & 11 & 0 & 0 & 1 \\
M 2 & & & & & & 12 & 5 & 0 & 0 & 3 \\
M 3 & & & & & & 1 & 8 & 1 & 3 & 0 \\
M 4 & & & & & & 0 & 13 & 9 & 10 & 14 \\
M 5 & & & & & 2 & 6 & 0 & 0 & 17 \\
\hline
\end{tabular}

staged as mature were most frequently shown to be ripe/running or spent histologically.

Histologically, the proportion of males that were staged as mature and ripe/running generally increased with length (Fig. 2), and spent males were most common between 26 and $40 \mathrm{~cm}$, above which they were not observed. Proportions of immature/resting and developing male gonads decreased with length (Fig. 2). In females, the histological stages immature/resting and developing were most common below $24 \mathrm{~cm}$, and mature, ripe/running and spent stages were most common above $24 \mathrm{~cm}$ (Fig. 2).

In the sample of blue cod gonads macroscopically staged in the survey $(\mathrm{n}=3247)$, males were most commonly staged as spent throughout the entire size range (Fig. 3). In the mid-size range $(30-40 \mathrm{~cm})$, the proportion of immature and maturing male stages decreased. Female blue cod had a high proportion of macroscopically staged spent gonads across all lengths (Fig. 3). The proportion of females staged as immature and maturing decreased with length, and the proportion of mature and ripe/running females increased with length. Macroscopic maturity stages at length for the subsample were representative of the larger sample (Fig. 4).

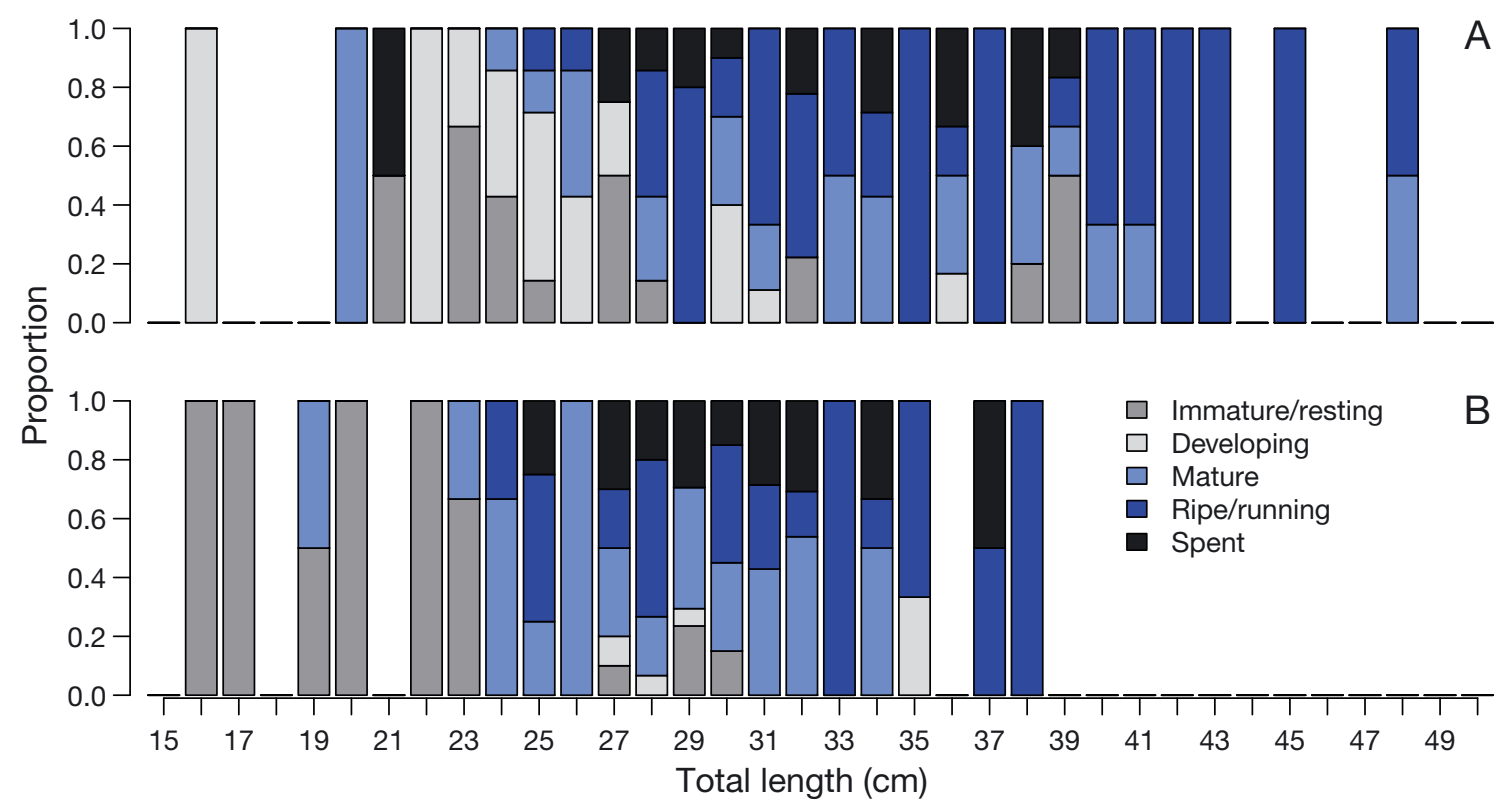

Fig. 2. Proportions of histological maturity classifications at length for (A) male and (B) female blue cod Parapercis colias $(\mathrm{n}=252)$ 


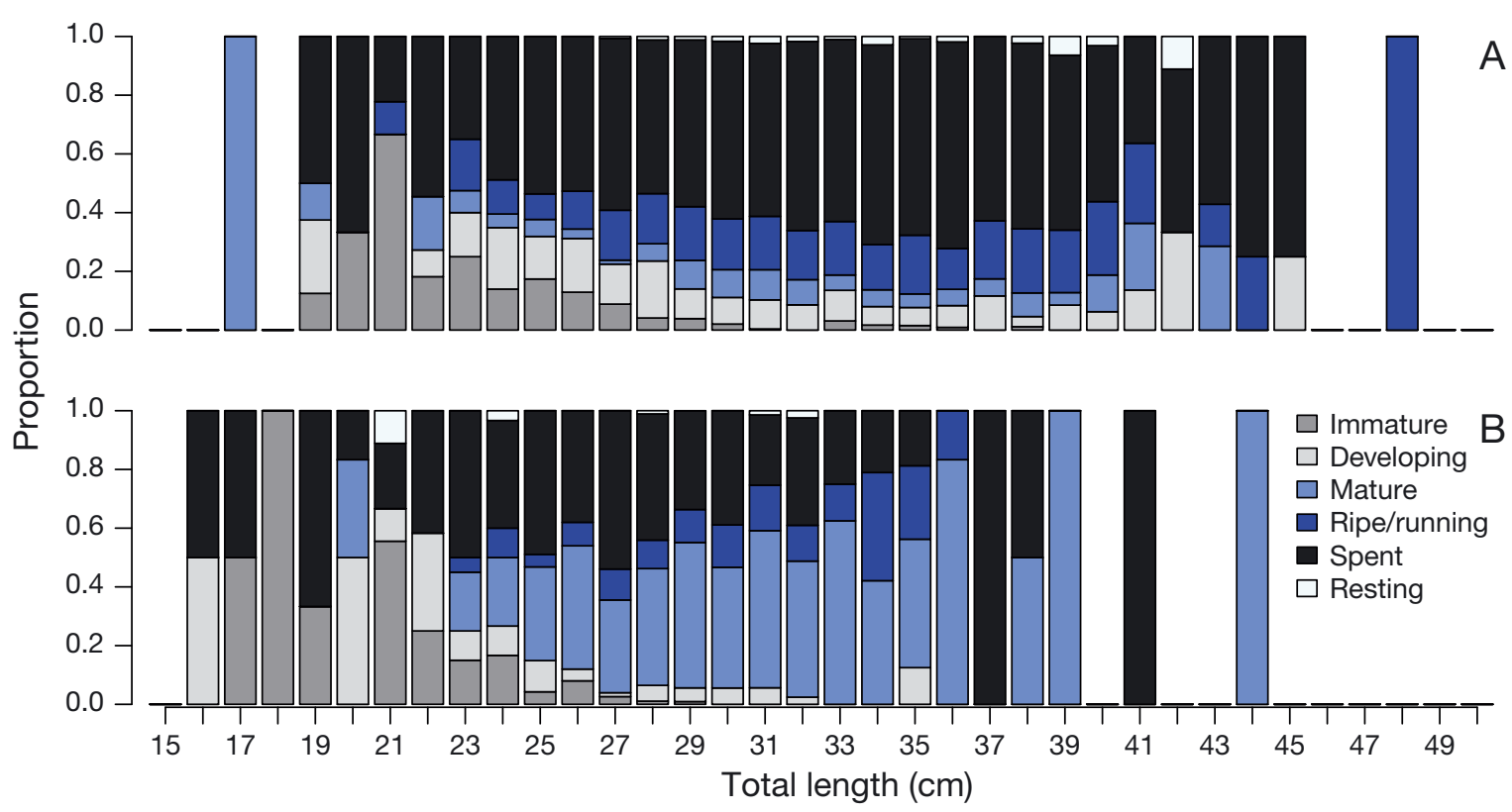

Fig. 3. Proportions of macroscopic maturity classifications at length for (A) male and (B) female blue cod Parapercis colias from the entire sample $(\mathrm{n}=3247)$

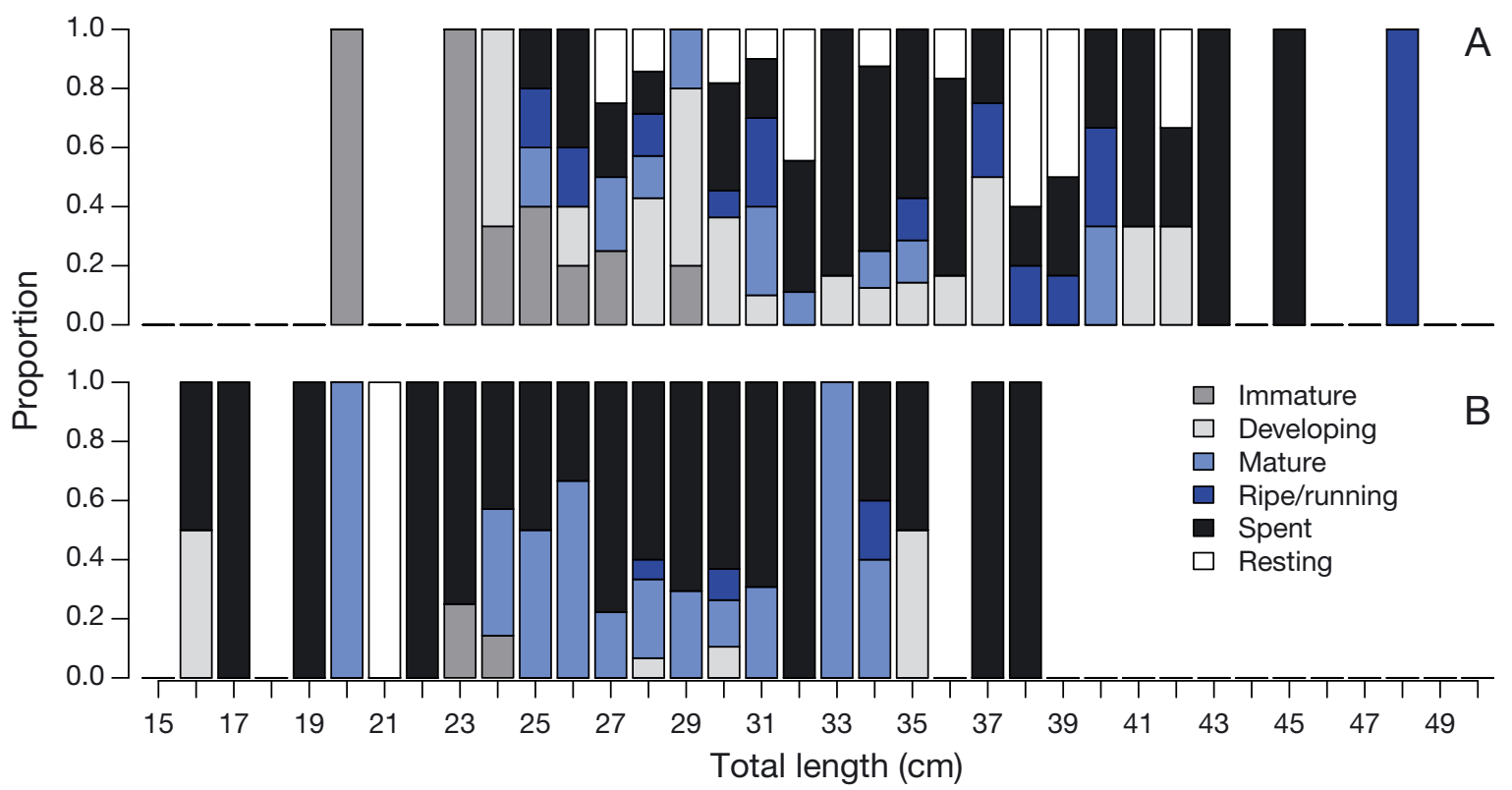

Fig. 4. Proportions of macroscopic maturity classifications for the histology subsample at length for (A) male and (B) female blue cod Parapercis colias $(\mathrm{n}=252)$

\section{Length-at-maturity}

Maturity ogives are illustrated in Fig. 5. When comparing between histological and macroscopic data from the same set of gonads (the histological subsample), female $L_{50}$ was underestimated by ca. $14 \mathrm{~cm}$ when macroscopic data were used, and male $L_{50}$ was overestimated by ca. $5 \mathrm{~cm}$ when macroscopic data were used (Tables $3 \& 4$ ). Male $L_{50}$ was ca.
$26 \mathrm{~cm}$ from histological data ( $\mathrm{n}=119$; Table 3 ), and female $L_{50}$ was ca. $23 \mathrm{~cm}$ from histological data $(\mathrm{n}=$ 124). Macroscopic maturity model parameters $L_{50}$ and $L_{\text {to95 }}$ from the histology subsample are shown in Table 4.

Male $L_{50}$ was estimated at ca. $31 \mathrm{~cm}$ when macroscopic data were used. Female $L_{50}$ was estimated at $8.5 \mathrm{~cm}$ when macroscopic data were used (Table 4). $L_{\text {to95 }}$ parameters for all macroscopic models using the 


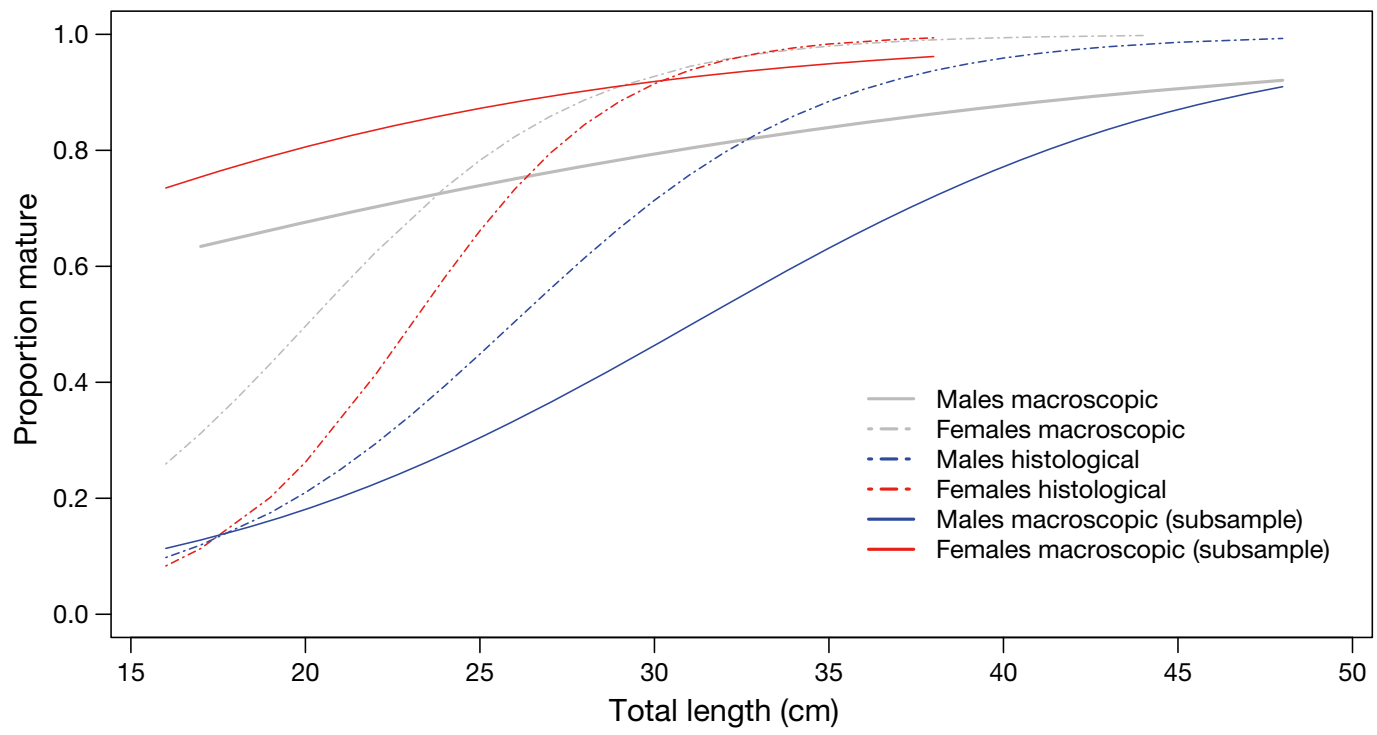

Fig. 5. Comparison of maturity ogives of blue cod Parapercis colias using macroscopic stages of the larger sample, histological stages of the histology subsample, and macroscopic stages of the histology subsample

subsample data were high, indicating relatively shallow curves. It was apparent from the proportion mature-at-length, and associated maturity ogives, that estimates of $L_{50}$ that fell below $16 \mathrm{~cm}$ were extrapolations from observations of larger fish. Those estimates are therefore best interpreted as being $<16 \mathrm{~cm}$.

The observation of macroscopic stage 5 fish (spent) across a wide range of length bins in the entire sample suggested that stage 5 might have been poorly determined or used as a default stage when macro-

Table 3. Estimates of $L_{50}$ and $L_{\text {to95 }}$ values (cm) for histological maturity ogives for blue cod Parapercis colias. These estimates were calculated from the histological subsample ( $\mathrm{n}=252$ )

\begin{tabular}{|llc|}
\hline Histological models & $L_{50}$ & $L_{\mathrm{to} 95}$ \\
\hline Female logistic least-squares & 23.04 & 5.24 \\
Male logistic least-squares & 26.0 & 11.6 \\
\hline
\end{tabular}

Table 4. Model estimates of $L_{50}$ and $L_{\text {to95 }}$ values $(\mathrm{cm})$ of macroscopically estimated maturity ogives for blue cod Parapercis colias. These estimates were calculated from the histological subsample $(\mathrm{n}=252)$

\begin{tabular}{|lrc|}
\hline Macroscopic models & \multicolumn{1}{c|}{$L_{50}$} & $L_{\text {to95 }}$ \\
\hline Female logistic least-squares & 8.5 & 24.6 \\
Male logistic least-squares & 30.7 & 23.0 \\
\hline
\end{tabular}

scopic staging was uncertain. To evaluate the sensitivity of the $L_{50}$ estimates to the use of this stage, the analyses were repeated after excluding all stage 5 fish. With stage 5 removed from the macroscopic data, the $L_{50}$ estimates were 27.8 and $23.8 \mathrm{~cm}$ for males and females (Table 5).

\section{Fecundity}

The mean \pm SD relative batch fecundity was $6.5 \pm$ $3.3 \mathrm{HOs} \mathrm{g}^{-1}$ body weight (BW). The average batch fecundity for a female between 25 and $38 \mathrm{~cm}$ was $2650 \pm 916$ HOs. No relationship between fish size, or fish BW, and batch fecundity was revealed (Fig. 6). There was a significant negative relationship between

Table 5. Sensitivities and model estimates of $L_{50}$ and $L_{\text {to95 }}$ values $(\mathrm{cm})$ of macroscopically estimated maturity ogives for blue cod Parapercis colias. These estimates were calculated from the larger sample $(n=3247)$

\begin{tabular}{|lcc|}
\hline Macroscopic sensitivities & $L_{50}$ & $L_{\mathrm{to} 95}$ \\
\hline $\begin{array}{l}\text { Male logistic least-squares } \\
\text { (larger sample) }\end{array}$ & 7.9 & 48.4 \\
$\begin{array}{l}\text { Female logistic least-squares } \\
\quad \text { (larger sample) }\end{array}$ & 20.3 & 12.0 \\
$\begin{array}{l}\text { Male logistic least-squares } \\
\text { (stage 5 removed) }\end{array}$ & 27.8 & 48.5 \\
$\begin{array}{l}\text { Female logistic least-squares } \\
\text { (stage 5 removed) }\end{array}$ & 23.8 & 4.6 \\
\hline
\end{tabular}



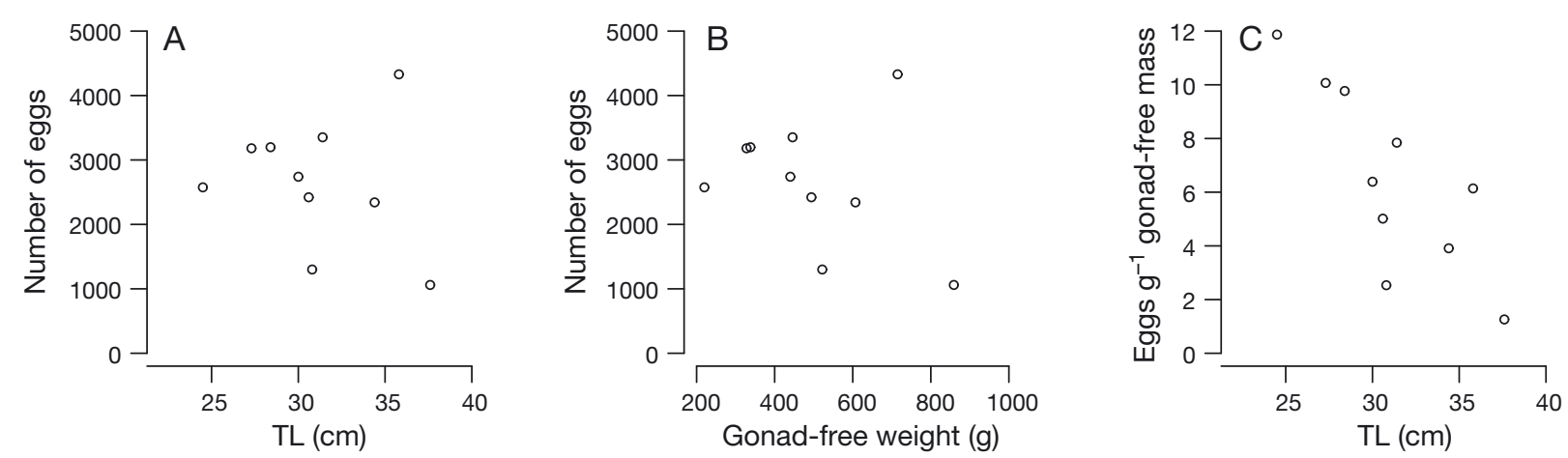

Fig. 6. Relationships between blue cod Parapercis colias (A) total length (TL) and batch fecundity (total number of hydrated oocytes in females not containing postovulatory follicles) (no significant relationship: $F_{1,19}=0.0045, \mathrm{p}=0.947$ ); (B) gonad-free weight and batch fecundity (no significant relationship: $F_{1,19}=0.6824 \mathrm{p}=0.419$ ); and $(\mathrm{C})$ TL and relative batch fecundity (hydrated oocytes $\mathrm{g}^{-1}$ gonad-free weight) (significant negative relationship: $F_{1,19}=4.641, \mathrm{p}=0.044$ )

relative fecundity and length (adjusted $\mathrm{R}^{2}=0.6147$, $F_{1,9}=15.36, \mathrm{p}<0.01$ ) and BW (adjusted $\mathrm{R}^{2}=0.6914$, $\left.F_{1,9}=21.16, \mathrm{p}<0.01\right)$, where the largest female sampled was the least fecund.

In histological sections of spawning females, ovaries containing POFs also contained many HOs; this observation prompted the analysis of fecundity in females containing POFs. Mean batch fecundity of ripe/running females without POFs was $2690 \pm 1013$ HOs and ranged from 1060 to 4329 eggs. Mean batch fecundity in ripe/running females with POFs was $2360 \pm 1882$ HOs and ranged from 262 to 6445 HOs. There was no significant difference in the mean number of HOs between females with and without POFs $\left(t_{15}=0.176, p=0.862\right)$. When data were combined, the overall mean fecundity was 2445 HOs

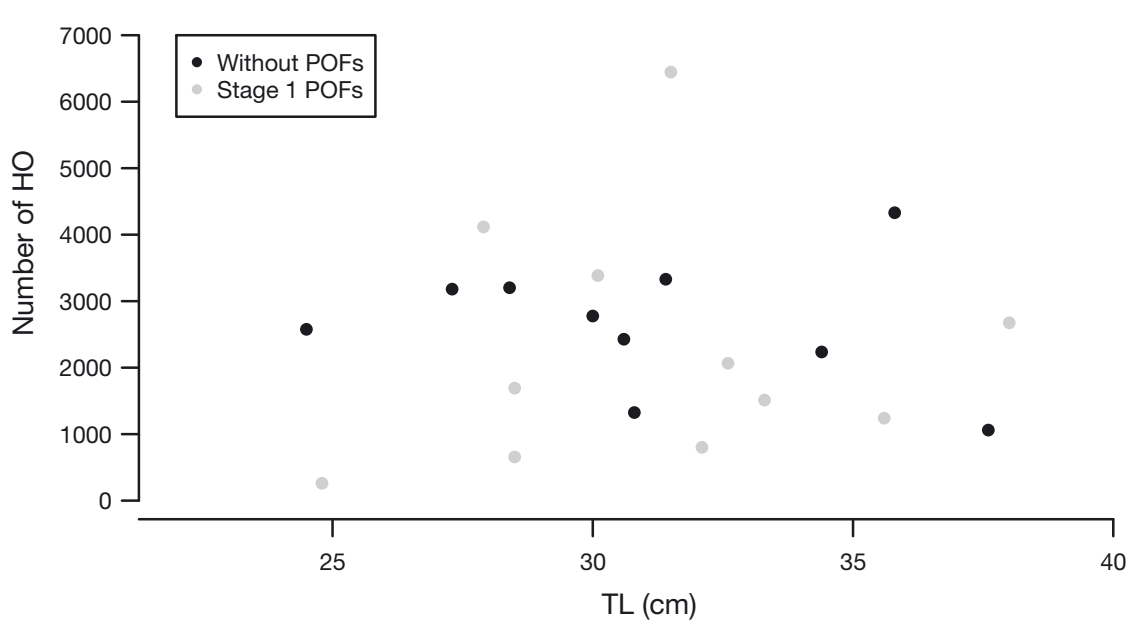

Fig. 7. Relationship between total length (TL) and batch fecundity (number of hydrated oocytes, HOs) in female blue cod Parapercis colias. Black dots are ripe/running females without postovulatory follicles (POFs) and grey dots are ripe/running females with POFs. The presence of POFs indicated that some ovulation of eggs had occurred female ${ }^{-1}$. Batch fecundity by length relationships did not indicate any trend in fecundity for fish length for females with or without POFs (Fig. 7).

Due to the low number of females with stage 1 POFs $(\mathrm{n}=49)$, it was not possible to get an accurate estimate of spawning frequency over a number of days. The only day of the survey that had a large sample size was Day 5, when 27 mature and ripe/running females were included in the histological sample (Table 6). Of these females, $29.6 \%$ had stage 1 POFs, corresponding to a spawning frequency of $4.6 \mathrm{~d}$. This indicated that fish between 25 and $30 \mathrm{~cm}$ spawned every $3 \mathrm{~d}$, whereas fish $>30 \mathrm{~cm}$ spawned every $4 \mathrm{~d}$ (Table 7). When the estimated spawning frequency, average overall batch fecundity and estimated spawning season of 7 mo (early June to late November, $182 \mathrm{~d}_{i}$ Shapiro \& Rasotto 1993) were combined, and assuming that spawning frequency and batch fecundity were constant over the spawning season, the average annual fecundity of a blue cod between 25 and $38 \mathrm{~cm}$ would be 104848 HOs.

\section{Hermaphroditism}

One individual had testicular tissue present in one lobe of the gonad and ovarian tissue in the other (Fig. 8A). The ovarian lobe contained atretic vitellogenic oocytes, and early vitellogenic oocytes were the most advanced stage of oocyte development. The testicular tissue resembled that of a developing male. This individual was 
Table 6. Spawning frequency, spawning fraction, day of the survey (from 26 September 2013) and sample size of mature and ripe/running blue cod Parapercis colias

\begin{tabular}{|lccc|}
\hline Day & $\begin{array}{c}\text { Spawning } \\
\text { fraction }\end{array}$ & $\begin{array}{c}\text { Spawning } \\
\text { frequency }\end{array}$ & $\begin{array}{c}\text { Sample } \\
\text { size }\end{array}$ \\
\hline 16 & 0.75 & 1.3 & 4 \\
15 & 1.00 & 1.0 & 1 \\
13 & 1.00 & 1.0 & 4 \\
12 & 1.00 & 1.0 & 1 \\
9 & 0.71 & 1.4 & 6 \\
5 & 0.30 & 4.6 & 27 \\
6 & 1.00 & 1.0 & 4 \\
2 & 1.00 & 1.0 & 2 \\
\hline
\end{tabular}

Table 7. Spawning fraction and spawning frequency by total length for blue cod Parapercis colias caught on Day $5(\mathrm{n}=27)$

\begin{tabular}{|lcc|}
\hline Fish length $(\mathrm{cm})$ & $\begin{array}{c}\text { Spawning } \\
\text { fraction }\end{array}$ & $\begin{array}{c}\text { Spawning } \\
\text { frequency }(\mathrm{d})\end{array}$ \\
\hline $25-30$ & 0.33 & 3.0 \\
$30+$ & 0.25 & 4.0 \\
Combined & 0.30 & 3.4 \\
\hline
\end{tabular}

$31.2 \mathrm{~cm}$ and weighed $475 \mathrm{~g}$. Macroscopic inspection of this gonad revealed that this condition could be determined by the naked eye (Fig. 8B), and this particular individual was classified at sea as 'unknown'. Other individuals were found that were functionally male but contained what appeared to be primary oocytes in the chromatin-nucleolus and perinucleolus stage (Fig. 9).

\section{DISCUSSION}

For the sample of blue cod assessed in this study, we found low agreement between histological and macroscopic maturity classifications. Our result might be caused by the difficulty in evaluating gonads macroscopically in a species with a complex maturation schedule. Blue cod fall into this category because they are thought to be protogynous hermaphrodites with an extended spawning period. Macroscopic staging for such species might always be particularly problematic.

Maturity ogives were fitted to macroscopic and histological maturity data from the subsample and to the macroscopic maturity data from the larger survey sample. These were used to estimate size-at-maturity. In the subsample, macroscopic staging underestimated the proportion of mature males in smaller length bins and overestimated $L_{50}$ (macroscopic $=$ $30.7 \mathrm{~cm}$, histology $=26.0 \mathrm{~cm}$ ). Macroscopic staging overestimated the proportion of mature females in the smaller length bins and underestimated $L_{50}$ $($ macroscopic $=8.5 \mathrm{~cm}$, histology $=23.0 \mathrm{~cm})$. In the larger sample, a large proportion of males across all length bins were classified as mature, which resulted in a considerably lower $L_{50}$ estimate $(7.9 \mathrm{~cm})$ than the histology estimate $(23.0 \mathrm{~cm})$. Female $L_{50}$ from the larger sample was lower $(20.3 \mathrm{~cm})$ compared to histology $(23.0 \mathrm{~cm})$. Misuse of macroscopic stage 5 was speculated, and therefore macroscopic analyses of the larger sample were repeated with this stage removed; $L_{50}$ estimates for both males and females with stage 5 removed were considerably closer to the histology estimates than the other macroscopic esti-
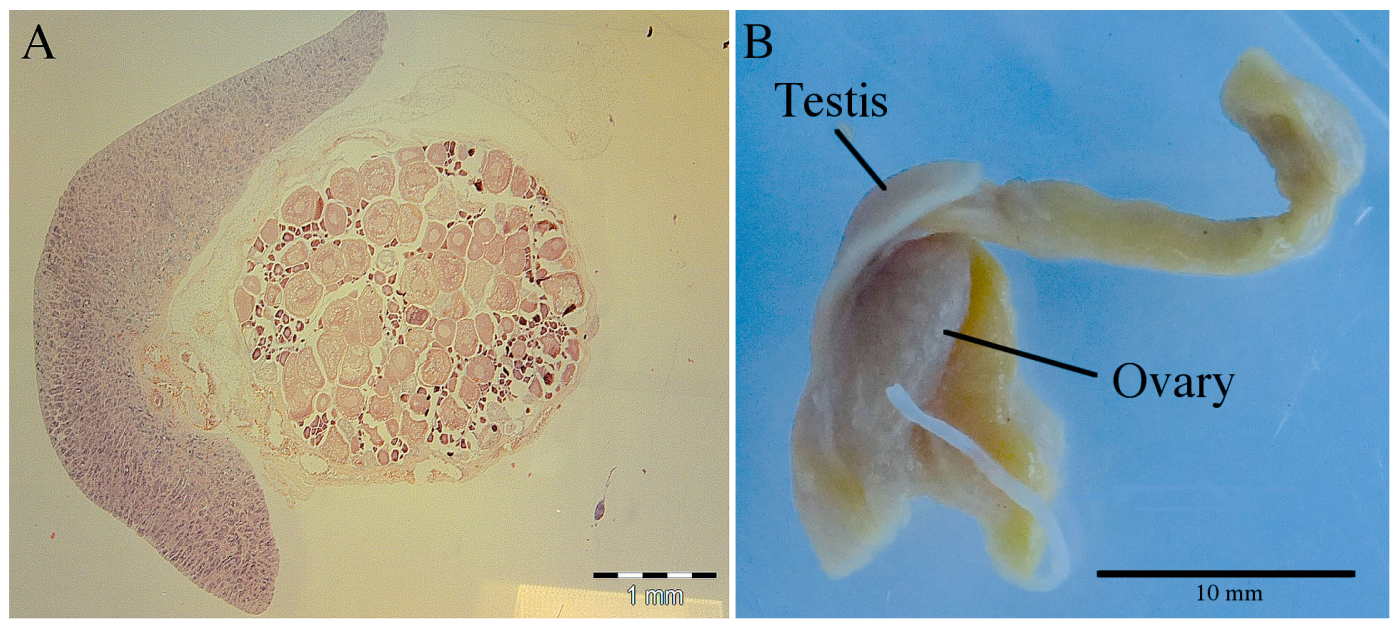

Fig. 8. Hermaphroditic blue cod Parapercis colias (A) histological section of the gonad stained with haematoxylin and eosin; the testis lobe (stage 2) is on the left and the ovarian lobe (stage 2a) is on the right; and (B) the same gonad with macroscopically identifiable testis and ovary 


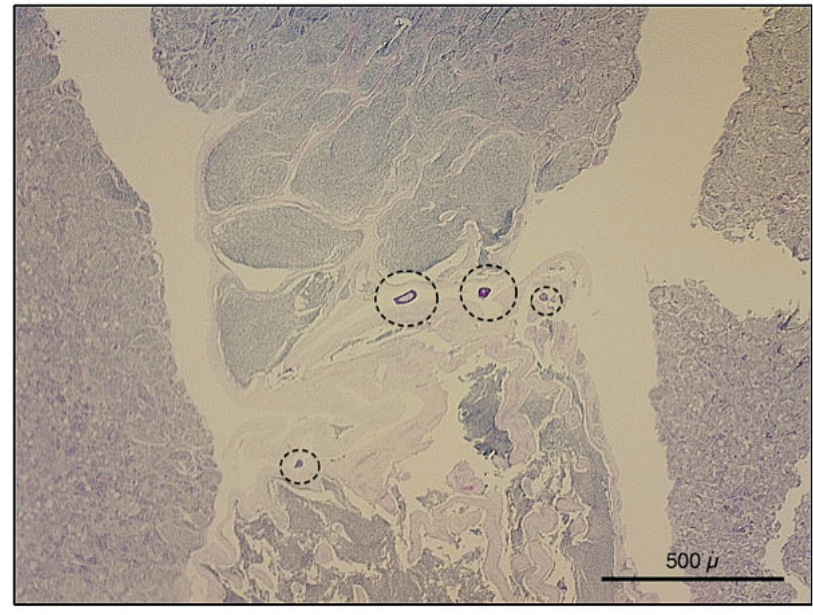

Fig. 9. Histological slide of testicular tissue from a blue cod Parapercis colias gonad stained with haematoxylin and eosin. Primary oocytes in the chromatin-nucleolus and perinucleolus stages found within the sperm duct of a ripe/running testis are outlined

mates $($ male $=27.8 \mathrm{~cm}$, female $=23.8 \mathrm{~cm})$. This suggests future evaluations of macroscopic size at maturity should exclude stage 5 .

The likely overuse of stage 5 may be the result of sampler bias or of a macroscopic maturity key that does not fit the species well. Stage 5 in the macroscopic key means 'spent'; however, the interpretation of this stage is ambiguous when macroscopically grading. Gonads of fish that have been squashed or mishandled during sampling can appear bruised when dissected, and because bruising is a common feature of spent gonads in macroscopic keys, this may lead to misclassification of maturity stage. Macroscopic keys are commonly unable to differentiate spent and resting gonads (Klibansky \& Scharf 2015). However, in this study, the macroscopically classified spent gonads were: (1) most often histologically mature or ripe/running in males; or (2) allocated across all histological classifications in females.

The composition of the histological subsample did not accurately reflect that of the larger sample. This was apparent with comparison of macroscopic $L_{50}$ estimates between the sample and subsample, which differed markedly. The subsample did not contain as high a proportion of small mature males (macroscopic classification) as the larger sample and contained a higher proportion of small mature females (macroscopic classification) than the larger sample. Although samples were intended to be random, there appears to have been some temporal, spatial or sampler bias when gonads were collected for histology at sea, as the disparity in length-at-maturity suggests they were not collected at random. Accurately correcting for such bias would require stratifying by sex, size and maturity stage, requiring a larger histological sample than obtained here (as extrapolation would be required), and was considered beyond the scope of the present study. However, the comparison between the histology and macroscopic classifications for the subsample is not affected by this potential bias and demonstrated the inaccuracy of the macroscopic maturity classifications.

Batch fecundity estimates presented here were much lower than in previous reports (Beer et al. 2013), where estimates were in the range of 1000 to $20000 \mathrm{HOs} \mathrm{g}^{-1}$ BW, compared to this study, where the greatest batch fecundity estimate was about $12 \mathrm{HOs} \mathrm{g}^{-1}$ BW. Comparatively, batch fecundity estimates for other finfish are 2-44 HOs $\mathrm{g}^{-1} \mathrm{BW}$ for Pinguipes brasilianus, another sandperch of the same family (Villanueva-Gomila et al. 2015), about $420 \mathrm{HOs} \mathrm{g}^{-1}$ BW for northern anchovy Engraulis mordax (Hunter \& Macewicz 1980) and $205 \mathrm{HOs} \mathrm{g}^{-1}$ BW in horse mackerel Trachurus trachurus (Karlou-Riga \& Economidis 1997). Blue cod batch fecundity estimates presented by Beer et. al. (2013) seem unfeasibly high; for example, using the estimates of Beer et al. (2013), 1 female weighing $933 \mathrm{~g}$ and $40 \mathrm{~cm}$ long (TL) was estimated to be carrying $20469 \mathrm{HOs} \mathrm{g}^{-1} \mathrm{BW}$, which equates to about 19 million HOs in total.

Although we did not find evidence for greater egg production in larger females, sample sizes were small, and larger female blue cod have been shown to produce more eggs in other studies (e.g. Beer et al. 2013). Furthermore, in some other species, larger, older females not only produce more eggs, but also produce larvae with higher survival success (Klibansky \& Scharf 2013, Carter et al. 2015). Therefore, although we found no increase in fecundity with female size, it is precautionary to continue to view large females as important contributors to population productivity. We note that the most fecund females in this study were at $25-27 \mathrm{~cm}$, which would indicate a peak in fecundity at a size close to the average size at first maturity for males. A reduction of relative fecundity in larger females might therefore be true, if mature females reaching the size where transition to male is beneficial started to reduce egg production and allocate resources instead towards a potential sex change.

The method used to age POFs has not been validated for blue cod and in this study was done by comparison to known-age POFs of carpenter seabream (Brouwer \& Griffiths 2005). Therefore, the estimates of spawning fraction and annual fecundity presented 
in this study are preliminary. The rate of deterioration in POFs can vary between species and with temperature (Hunter \& Macewicz 1985). POF ages can be validated by inducing ovulation in ripe/running females, euthanizing them at known times past ovulation, then histologically processing the ovarian tissues and documenting the rate of deterioration in POFs over time (Fitzhugh \& Hettler 1995, Alday et al. 2008). Spawning frequency may differ between size classes of females and may change throughout the spawning season (Hunter \& Macewicz 1985, Brouwer \& Griffiths 2005). In this study, the estimate of spawning frequency was derived from ripe/running females from 1 sampling day only. To get a more accurate estimate of spawning frequency, POF degeneration needs to be documented for blue cod, and mature females must be collected throughout the spawning season.

We noted that some females that had early-stage POFs (indicating recent ovulation) also had HOs and later-stage POFs. This observation suggested continuality of the spawning process rather than distinct spawning episodes. Conventional methods assume that once POFs are seen within the ovary, ovulation has occurred and it is possible that spawning has occurred, thereby reducing the number eggs available for the fecundity counts; therefore, the individual ovary is unfit for fecundity analysis due to likely underestimation of fecundity (Claramunt et al. 2007). When ovaries containing both HOs and early-stage POFs were analysed alongside those with no POFs but with HOs, we found no significant difference in batch fecundity estimates. This may suggest that in blue cod spawning events, eggs are released over some time rather than in distinct episodes, or hydration occurs rapidly following ovulation. Alternatively, following ovulation, eggs could remain within the ovary for a length of time, or it may be that POFs degenerate very slowly in blue cod. This highlights the need for POF age validation for blue cod and additional sampling of ripe/running females.

Some evidence for blue cod sex change was found in a single blue cod gonad that contained a testicular lobe and an ovarian lobe. The testicular and ovarian tissues of the hermaphroditic gonad were macroscopically identifiable. Primary oocytes were also found within ripe/running testicular tissue in other blue cod samples. Additional samples of sex-changing gonads at various developmental stages are needed to distinguish between resting ovaries and early sex change gonads. Furthermore, a study of the early gonadal development in this species is also warranted to elucidate if and how sex change takes place.
The histological and macroscopic stages do mark equivalent steps in sexual development (developing, mature, ripe/running, etc.), but the maturation process is continuous and does not follow discrete steps. The histological key was designed to be objective and precise by using distinguished changes in oocyte and spermatocyte development to mark the progression of maturity. These same changes are not identifiable macroscopically, so the comparison of the 2 sets of maturity stages for the same sample would be expected to differ somewhat due to lack of precision in the macroscopic key. Nevertheless, the observed differences between macroscopic and histological classifications were great enough to conclude that the classifications made by the macroscopic key were inaccurate. There may be an issue with the key or the ability of technical staff to distinguish between stages of the key. This highlights the need for better training of technicians in the macroscopic staging of blue cod.

As a result, by using macroscopic maturity estimates from the sample, $L_{50}$ was underestimated. An underestimate of $L_{50}$ would lead to an overestimate of the SSB. Taken together with the estimates of fecundity calculated in this study, which were markedly lower than previously published estimates, the absolute productivity of blue cod stocks may be considerably lower than previously thought. In addition, the problems we have found in accurately determining maturity in blue cod show that the measurement of key biological parameters is particularly difficult, or more sufficient training needs to take place, and therefore the accuracy of stock assessment and scientific advice for fishery management decisions is more uncertain.

Acknowledgements. We thank A. Hoverd, J. Pitman and A. Jones for histological expertise; D. McNaughtan and J. Van der Sman for technical laboratory advice and help at Victoria University Coastal Ecology Lab; and the Ministry for Primary Industries and the National Institute of Water and Atmospheric Research for obtaining blue cod samples in the field and providing survey data.

\section{LITERATURE CITED}

Alday A, Uriarte A, Santos M, Martín I, Martinez de Murguia A, Motos L (2008) Degeneration of postovulatory follicles of the Bay of Biscay anchovy (Engraulis encrasicolus L.). Sci Mar 72:565-575

Alonzo SH, Ish T, Key M, MacCall AD, Mangel M (2008) The importance of incorporating protogynous sex change into stock assessments. Bull Mar Sci 83:163-179

Beentjes MP, Carbines GD (2005) Population structure and relative abundance of blue cod (Parapercis colias) off Banks Peninsula and in Dusky Sound, New Zealand. N Z 
J Mar Freshw Res 39:77-90

Beentjes MP, Carbines GD (2012) Relative abundance, size and age structure, and stock status of blue cod from the 2010 survey in Marlborough Sounds, and review of historical surveys. New Zealand Fisheries Assessment Report 2012/43. Ministry for Primary Industries, Wellington

Beer N, Wing S, Carbines G (2013) First estimates of batch fecundity for Parapercis colias, a commercially important temperate reef fish. N Z J Mar Freshw Res 47: 587-594

Birkeland C, Dayton PK (2005) The importance in fishery management of leaving the big ones. Trends Ecol Evol 20:356-358

Brouwer SL, Griffiths M (2005) Reproductive biology of carpenter seabream (Argyrozona argyrozona) (Pisces: Sparidae) in a marine protected area. Fish Bull 103:258-269

Brown-Peterson NJ, Wyanski DM, Saborido-Rey F, Macewicz BJ, Lowerre-Barbieri SK (2011) A standardized terminology for describing reproductive development in fishes. Mar Coast Fish 3:52-70

Carbines GD (2004) Age, growth, movement and reproductive biology of blue cod (Parapercis colias, Pinguipedidae): implications for fisheries management in the South Island of New Zealand. PhD dissertation, University of Otago

Carter AB, Carton AG, McCormick MI, Tobin AJ, Williams AJ (2015) Maternal size, not age, influences egg quality of a wild, protogynous coral reef fish Plectropomus leopardus. Mar Ecol Prog Ser 529:249-263

Claramunt G, Serra R, Castro L, Cubillos L (2007) Is the spawning frequency dependent on female size? Empirical evidence in Sardinops sagax and Engraulis ringens off northern Chile. Fish Res 85:248-257

Cole RG, Davey NK, Carbines GD, Stewart R (2012) Fishhabitat associations in New Zealand: geographical contrasts. Mar Ecol Prog Ser 450:131-145

Fitzhugh GR, Hettler W (1995) Temperature influence on postovulatory follicle degeneration in Atlantic menhaden, Brevoortia tyrannus. Fish Bull 93:568-572

Grier HJ (1981) Cellular organization of the testis and spermatogenesis in fishes. Am Zool 21:345-357

* Hawkins JP, Roberts CM (2004) Effects of fishing on sexchanging Caribbean parrotfishes. Biol Conserv 115: 213-226

Hunter J, Macewicz BJ (1980) Sexual maturity, batch fecundity, spawning frequency, and temporal pattern of spawning for the northern anchovy, Engraulis mordax, during the 1979 spawning season. Calif Coop Ocean Fish Invest Rep 21:139-149

Hunter JR, Macewicz BJ (1985) Measurement of spawning frequency in multiple spawning fishes. In: Lasker $\mathrm{T}$ (ed) An egg production method for estimating spawning biomass of pelagic fish: application to the northern anchovy, Engraulis mordax. Tech Rep 36. US Dept Commerce, NOAA, NMFS, Springfield, VA, p 79-84

Kamler E (2005) Parent-egg-progeny relationships in teleost fishes: an energetics perspective. Rev Fish Biol Fish 15:399-421

Karlou-Riga C, Economidis PS (1997) Spawning frequency and batch fecundity of horse mackerel, Trachurus trachurus (L.), in the Saronikos Gulf (Greece). J Appl

Editorial responsibility: Helmut Segner,

Bern, Switzerland
Ichthyol 13:97-104

Klibansky N, Scharf F (2013) Size-dependent and temporal variability in batch number and fecundity of red porgy, a protogynous, indeterminate spawner, in the U.S. South Atlantic. Mar Coast Fish 5:39-52

Klibansky N, Scharf F (2015) Success and failure assessing gonad maturity in sequentially hermaphroditic fishes: comparisons between macroscopic and microscopic methods. J Fish Biol 87:930-957

McMillan DB (2007) Fish histology: female reproductive systems. Springer Science \& Business Media, Dordrecht

* Morgan MJ (2008) Integrating reproductive biology into scientific advice for fisheries management. J Northwest Atl Fish Sci 41:37-51

MPI (Ministry for Primary Industries) (2015) Fisheries assessment plenary June 2015: stock assessments and stock status. Vol 1: Introductory sections to Hoki. Book 1. Compiled by the Fisheries Science Group, Ministry for Primary Industries, Wellington

Mutch PG (1983) Factors influencing the density and distribution of the blue cod (Parapercis colias) (Pisces: Mugiloididae). PhD dissertation, University of Auckland

Nelson JS (2006) Fishes of the world. John Wiley \& Sons, New York, NY

R Core Team (2015) R: a language and environment for statistical computing. R Foundation for Statistical Computing, Vienna

Rapson A (1956) Biology of the blue cod (Parapercis colias Forster) of New Zealand. PhD dissertation, Victoria University of Wellington

Sadovy Y, Shapiro DY (1987) Criteria for the diagnosis of hermaphroditism in fishes. Copeia 1987:136-156

Shapiro D, Rasotto MB (1993) Sex differentiation and gonadal development in the diandric, protogynous wrasse, Thalassoma bifasciatum (Pisces, Labridae). J Zool 230: 231-245

Siau Y (1994) Population structure, reproduction and sexchange in a tropical East Atlantic grouper. J Fish Biol 44: 205-211

* Trip E, Clements K, Raubenheimer D, Choat J (2011) Reproductive biology of an odacine labrid, Odax pullus. J Fish Biol 78:741-761

*Venerus L, Parma A, Galván D (2008) Annual occupation pattern of temperate rocky reefs by the Argentine sandperch Pseudopercis semifasciata in San José Gulf Marine Park, Argentina. Fish Manag Ecol 15:217-229

Villanueva-Gomila GL, Macchi GJ, Ehrlich MD, Irigoyen AJ, Venerus LA (2015) The reproductive biology of Pinguipes brasilianus Cuvier, 1829 (Osteichthyes: Pinguipedidae) in temperate rocky reefs of Argentina. Neotropical Ichthyol 13:733-744

* Vitale F, Svedäng H, Cardinale M (2006) Histological analysis invalidates macroscopically determined maturity ogives of the Kattegat cod (Gadus morhua) and suggests new proxies for estimating maturity status of individual fish. ICES J Mar Sci 63:485-492

West G (1990) Methods of assessing ovarian development in fishes: a review. Mar Freshw Res 41:199-222

Wilson CA, Nieland DL (1994) Reproductive biology of red drum, Sciaenops ocellatus, from the neritic waters of the northern Gulf of Mexico. Fish Bull 92:841-850

Submitted: July 18, 2016; Accepted: June 14, 2017

Proofs received from author(s): August 24, 2017 